\title{
FLOW CHARACTERISTICS OF RECTANGULAR BROAD-CRESTED WEIRS WITH SLOPED UPSTREAM FACE
}

\author{
EHSAN GOODARZI ${ }^{1)}$, JAVAD FARHOUDI ${ }^{2)}$, NASER SHOKRI ${ }^{3)}$ \\ ${ }^{1)}$ School of Civil and Environmental Engineering, Georgia Institute of Technology, USA; \\ +1-(404)944-6539, Mailto: ehsan.g@hotmail.com \\ ${ }^{2)}$ Department of Irrigation \&Reclamation, Faculty of soil \& Water Eng., University of Tehran, Iran. \\ ${ }^{3)}$ Ministry of Energy, Fars Regional Water Authority, Shiraz, Iran.
}

\begin{abstract}
The hydraulic characteristics of flow over rectangular broad-crested weirs with varying upstream slopes were experimentally studied. A series of laboratory experiments was performed to investigate the effects of changing upstream slopes from $90^{\circ}$ to $75^{\circ}, 60^{\circ}, 45^{\circ}, 30^{\circ}, 22.5^{\circ}, 15^{\circ}$, and $10^{\circ}$ on the flow surface pattern, discharge coefficient values, approach velocity profile and flow separation zone. In addition, a new mathematical relationship for water surface profile and a new correction factor to estimate discharge coefficient over weirs with various upstream slopes were introduced. The results showed decreasing upstream slopes from $90^{\circ}$ to $10^{\circ}$ leading to increasing discharge coefficient values and dissipation of the separation zone.
\end{abstract}

KEY WORDS: Broad Crested Weir, Upstream Face Slope, Flow Surface Pattern, Discharge Coefficient, Correction Factor, Separation Zone, Velocity Profile.

Ehsan Goodarzi, Javad Farhoudi, Naser Shokri: PRIETOKOVÉ CHARAKTERISTIKY PRAVOUHLÉHO PRIEPADU SO ŠIROKOU PRIEPADOVOU HRANOU SO SKLONENÝM NÁVODNÝM POVRCHOM. J. Hydrol. Hydromech., 60, 2012, 2; 20 lit., 15 obr., 2 tab.

Práca obsahuje výsledky experimentálneho štúdia prietoku vody cez pravouhlý priepad so širokou priepadovou hranou s rozdielnymi sklonmi návodného povrchu priepadu. Uskutočnili sme sériu laboratórnych pokusov s ciel'om štúdia vplyvu rôznych sklonov návodného povrchu priepadu od $90^{\circ}, 75^{\circ}$, $60^{\circ}, 45^{\circ}, 30^{\circ}, 22,5^{\circ}, 15^{\circ}$, až po $10^{\circ}$ na tvar hladiny, hodnoty prietokového súčinitel'a, rýchlostné profily a na prúdenie v oblasti separácie. Okrem toho boli zistené nové matematické vzt’ahy na výpočet tvaru hladiny, ako aj nové korekčné faktory na určenie prietokových súčinitel'ov cez priepad s rozdielnymi sklonmi návodného povrchu. Z výsledkov vyplýva, že znižujúce sa sklony návodného povrchu priepadu od $90^{\circ}$ po $10^{\circ}$ vedú k zvýšeniu prietokového súčinitel’a a k disipácii oblasti separácie.

KLÚČOVÉ SLOVÁ: priepad širokou priepadovou hranou, sklon návodného povrchu, tvar povrchu hladiny, výtokový koeficient, korekčný faktor, oblast’ separácie, profily rýchlosti prúdenia.

\section{Introduction}

Flow measurement is the quantification of fluid movement parameters. Since the early days of hydraulics, various flow measuring devices such as hydraulic structures have been developed and used in waterways. Hydraulic structures have been installed in open channels or rivers with a free water level to estimate discharge based on the measured upstream water level (Boiten, 1993). For instance, weirs as a type of hydraulic structure are consisting of some obstruction to increase water level and commonly used to measure discharge.

Flow measurement in hydraulic structures can be mainly classified into two main methods, (1) the hydraulic head method, and (2) the velocity areas method. In the first method, flow discharge is determined by measuring the hydraulic head difference through the flow reach, while in the second method flow discharge is obtained by measuring the local velocities along with their affected areas. These methods are mostly concluded with some empirical equations between discharge and flow head, and sometimes they may differ from field measurements. One of the most widely used hydraulic structures for measuring flow rates in open channels and rivers is a rectangular broadcrested weir. It is a common engineering structure with a horizontal crest above which the streamlines are practically straight and parallel. This simple 
structure has often been used in irrigation systems, hydroelectric schemes, and highways. Some of the most common broad-crested weirs are rectangular broad-crested weirs with $90^{\circ}$ upstream face slope, rectangular round edged broad-crested weirs, and triangular broad-crested or crump weirs. Among these weirs, the simplest is the square-edged weir (edge refers to the entrance from the approach channel) with rectangular cross section. The main advantages of rectangular broad-crested weirs with $90^{\circ}$ upstream face slope include constant discharge coefficient in optimum flow condition, less sensitivity to downstream submergence, simple design and construction, and low construction and utility costs.

In particular situations, the weir's structural design can present some flexibility for modifying the upstream face slopes to provide better hydraulic characteristics and measure discharge efficiency at higher precision. Hence, different models of broadcrested weirs with a rectangular compound cross section were analyzed experimentally in this study. The upstream slope of desire weir has been changed from $90^{\circ}$ to $75^{\circ}, 60^{\circ}, 45^{\circ}, 30^{\circ}, 22.5^{\circ}, 15^{\circ}$, and $10^{\circ}$ to investigate:

1. The effects of changing the upstream slope of a rectangular broad-crested weir on discharge coefficient,

2. Changing velocity profiles over the crest of different sloped weirs along the flow direction, and

3. The effect of a separation zone on flow characteristics.

\section{Literature review}

The flow characteristics of broad-crested weirs with different cross sections have been of interest to many researchers. Woodburn (1932) showed that flow passes through a critical stage at some section at the crest of a broad-crested weir and the location of this section varies according to hydrostatic head and weir dimensions. In addition, he presented a depth-discharge relationship based on the relationships between overflow capacity, discharge coefficient, weir width, and the upstream water head. Govinda Rao and Muralidhar (1963) classified rectangular weirs in four categories based on the total energy head upstream of the weir $H_{1}$ and the crest length $L$ as follows: rectangular long-crested weirs, rectangular broad-crested weirs, rectangular short-crested weirs, and rectangular sharp-crested weirs. Hall (1962) applied the boundary layer theo- ry and presented a new expression for the free-flow characteristics of broad-crested weirs with $90^{\circ}$ upstream face slope. Singer (1964) reported that the discharge coefficient of broad crested weirs $\left(C_{d}\right)$ depends on weir height $(P)$ as well as crest length $(L)$. It was also expressed that the discharge coefficient is a function of $H_{1} / P$ and $H_{1} /\left(H_{1}+P\right)$, while critical depth over the crest will occur if both of the following conditions are fulfilled:

$0.08 \leq \frac{H_{1}}{L} \leq 0.33$

and

$0.18 \leq \frac{H_{1}}{H_{1}+P} \leq 0.3$,

where $H_{1}$ is the total energy head upstream of the weir, $h_{1}$ - the overflow head upstream of the weir, and $P$ and $L$ are weir height and length, respectively.

Based on the above conditions, a region of parallel flow will occur somewhere midway above the crest. The water surface slopes downward at both the beginning and near the end of the crest. From a hydraulic point of view, the weir may be described as broad-crested over this range only and the control section is located at the end of the section where parallel flow occurs.

Harrison (1967) presented a new coefficient of discharge for a streamlined broad-crested weir based on the critical flow theory. Rao and Shukla (1971) carried out an experimental investigation measuring the effect of finite crest length on discharge characteristics of broad-crested weirs with $90^{\circ}$ upstream face slope. Ramamurthy et al. (1988) studied the effects of rounding the upstream edge of a broad-crested weir on flow characteristics through experimental investigation. Hager and Schwalt (1994) showed that the broad-crested weir with $90^{\circ}$ upstream face slope is more accurate than with a round-edged upstream face. Baylar and Emiroglu (2002) studied the air entrainment rate of a $30^{\circ}$ triangular sharp-crested weir and compared the results with other sharp-crested weirs with different cross-sectional geometry. Ghodsian (2003) investigated the hydraulics of sharp-crested rectangular side weirs under supercritical flow. Farhoudi and Shahalami (2005) proposed the flow pattern governing hydraulic principles of rectangular broadand short-crested weirs. Borghei et al. (2006) studied oblique rectangular sharp-crested weirs for 
submerged and free-flow conditions and a stagedischarge relationship was developed based on the ISS theory. Farhoudi and Shokri (2007) experimentally determined the flow characteristics of the broad-crested rectangular weirs with a sloped downstream face. They considered the effects of downstream slope on weir discharge efficiency and its sensitivity to downstream submergence ratio. Ramamurthy et al. (2009) applied a $k-\varepsilon$ model to determine various flow characteristics such as velocity distribution, water surface profile and pressure distribution over a sharp-crested weir in a rectangular open channel. Sargison and Percy (2009) investigated the flow of water over a trapezoidal broad-crested or embankment weir with varying upstream and downstream slopes. In their study, the effect of $2 \mathrm{H}: 1 \mathrm{~V}, 1 \mathrm{H}: 1 \mathrm{~V}$ and vertical slopes in various combinations on the weir upstream and downstream faces were compared. Haun et al. (2011) applied two computational fluid dynamics (CFD) codes, Flow 3D and SSIIM2, to calculate the water flow over a trapezoidal broad-crested weir.

Many studies, including those referenced above, have considered the effects of different broadcrested weir designs on flow characteristics, while only few studies in literature investigated a wide range of varying upstream slopes in rectangular broad-crested weirs (i.e. from $90^{\circ}$ to $10^{\circ}$ ). Hence, the present study includes considering the effects of changing the upstream slopes of rectangular broadcrested weirs on water surface pattern, discharge coefficient values, approaching velocity profile, and flow separation zones.

\section{Theoretical assessment}

The theoretical relationships for assessing the flow characteristics of rectangular broad-crested weirs are based on the relation between discharge and upstream water level. The relation can be set up from a theoretical approach mostly carried out by a hydraulic model study. However, a number of assumptions should be made for simplicity and some adjustments are necessary for real fluids by introducing a coefficient. The assumptions used in this study are as follows:

1. The flow lines are parallel and hydrostatic pressure distribution over the crest prevails,

2. Boundary layer thickness is overlooked compared to flow depth over the crest,

3 . The velocity distribution follows a uniform pattern in the outer layer (Bos, 1985).
Based on continuity and Bernoulli's equations, the discharge relation for flow over a broad-crested weir can be written as:

$Q=C_{d}\left[\frac{2}{3}\left(\frac{2}{3} g\right)^{1 / 2}\right] B \cdot H_{1}^{3 / 2}$,

where, $H_{1}=h_{1}+h_{v}, h_{v}$ is the approaching flow's velocity head equal to $v^{2} /(2 g), h_{1}$ - the overflow head upstream of the weir $[\mathrm{m}], v-$ the approach mean velocity $\left[\mathrm{m} \mathrm{s}^{-1}\right]$ where $h_{1}-$ determined, and $B$ - the weir's breadth which spans the full channel width.

In general, it is not possible to directly measure the total energy head $H_{1}$ in a field installation, while in places where the approach velocity is very low the velocity head component $\left(h_{v}\right)$ can be neglected, and so $H_{1}$ in Eq. (1) can be replaced by $h_{1}$ (Bettez et al., 2001). Therefore, the common practice of relating discharge to the upstream water level over the crest can be written as

$Q=C_{d}\left[\frac{2}{3}\left(\frac{2}{3} \mathrm{~g}\right)^{1 / 2}\right]$ B. $h_{1}^{3 / 2}$

where $Q$ is flow discharge $\left[\mathrm{m}^{3} \mathrm{~s}^{-1}\right], \mathrm{g}$ - gravitational acceleration $\left[\mathrm{m} \mathrm{s}^{-2}\right.$ ], and $C_{d}$ is discharge coefficient.

Reports by various researchers indicate that the result determined by Eq. (2) derived from field measurements may be attributed to the assumption made in achieving Eq. (1). Apparently this deviation affects the value of $C_{d}$ in Eqs. (1) and (2) which emphasize the correct determination of the weir discharge coefficient (Bhaskar and Nigam, 1990).

\section{Experimental layout}

Experimental measurements were conducted in a research flume with a cross section $0.25 \mathrm{~m}$ wide, $0.50 \mathrm{~m}$ deep and $12 \mathrm{~m}$ long (Fig. 1). Low tail water level was maintained, and it did not affect the oncoming flow for all cases. The weirs were constructed from two main parts: the upstream face or wedge section, and the rectangular part or core segment, in which the upstream faces were interchanged in order to produce different combinations of upstream slopes and rectangular sections. The central part's length was $0.60 \mathrm{~m}$ (or $L=0.60 \mathrm{~m}$ ) while height and width were $0.25 \mathrm{~m}$ (or $P=B=$ $=0.25 \mathrm{~m}$ ). The rectangular section was prepared and secured as the structure's central core across 
the whole flume width with $1.2 \mathrm{~m}$ distances from the upstream water entrance tank. Furthermore, eight wedges with different slopes and sizes were prepared and added to the central structure core in each individual experiment layout. Water proof glue was carefully applied for water tightening of the upstream face. The flow was led to the flume through an upstream tank which was fed from a main reservoir and controlled by an adjustable tool. In the next step, flow with discharges of 0.015 , $0.020,0.025,0.030$ and $0.035\left[\mathrm{~m}^{3} \mathrm{~s}^{-1}\right]$ was passed downstream over the weir. It should be noted that the flow rate was adjusted using a pre-calibrated sharp-crested rectangular weir installed at the upstream tank's entrance and volumetric flow rate was measured downstream of the weir using a $90^{\circ}$ $\mathrm{V}$-notch weir with an accuracy of $\pm 0.01\left[1 \mathrm{~s}^{-1}\right]$. In addition, the flume was equipped with a hinged gate to regulate the downstream water depth. The water surface profiles were determined vertically and horizontally to $\pm 0.1 \mathrm{~mm}$ using a point gauge on a traverse apparatus at different static points spaced 0.05 and $0.10 \mathrm{~m}$ apart (Fig. 2). A pitot tube was used to measure the velocity profiles along the flow direction and over the weir crest. The basic pitot tube consists of a tube pointing directly into the fluid flow and it measures fluid velocity by converting the flow's kinetic energy into potential energy. Conversion takes place at the stagnation point, located at the pitot tube's entrance. Based on
Bernoulli's equation, the stagnation or total pressure can be computed as:

$p_{t}=p_{s}+\left(\frac{\rho v^{2}}{2}\right)$.

Solving that for velocity, we get:

$v=\sqrt{\frac{2\left(p_{t}-p_{s}\right)}{\rho}}$

where $v$ is fluid velocity, $p_{t}-$ stagnation or total pressure, $p_{s}$ - static pressure, and $\rho$ is fluid density.

The relationship between pressure drop $\Delta p$ or $p_{t}-p_{s}$ due to $\Delta h$, can be written as:

$\Delta p=\rho \mathrm{g} \Delta h$,

where $\Delta h$ is the manometer reading.

In this study, a total of 40 laboratory experiments including eight different broad-crested weir models with rectangular compound cross sections and five different discharges, were conducted in a horizontal laboratory flume $12.0 \mathrm{~m}$ long, $0.25 \mathrm{~m}$ wide, and $0.50 \mathrm{~m}$ deep in order to investigate the effects of changing the upstream slopes of rectangular broadcrested weirs on the values of discharge coefficient, water profile and the approach velocity profile. The achieved results are presented in the following sections.

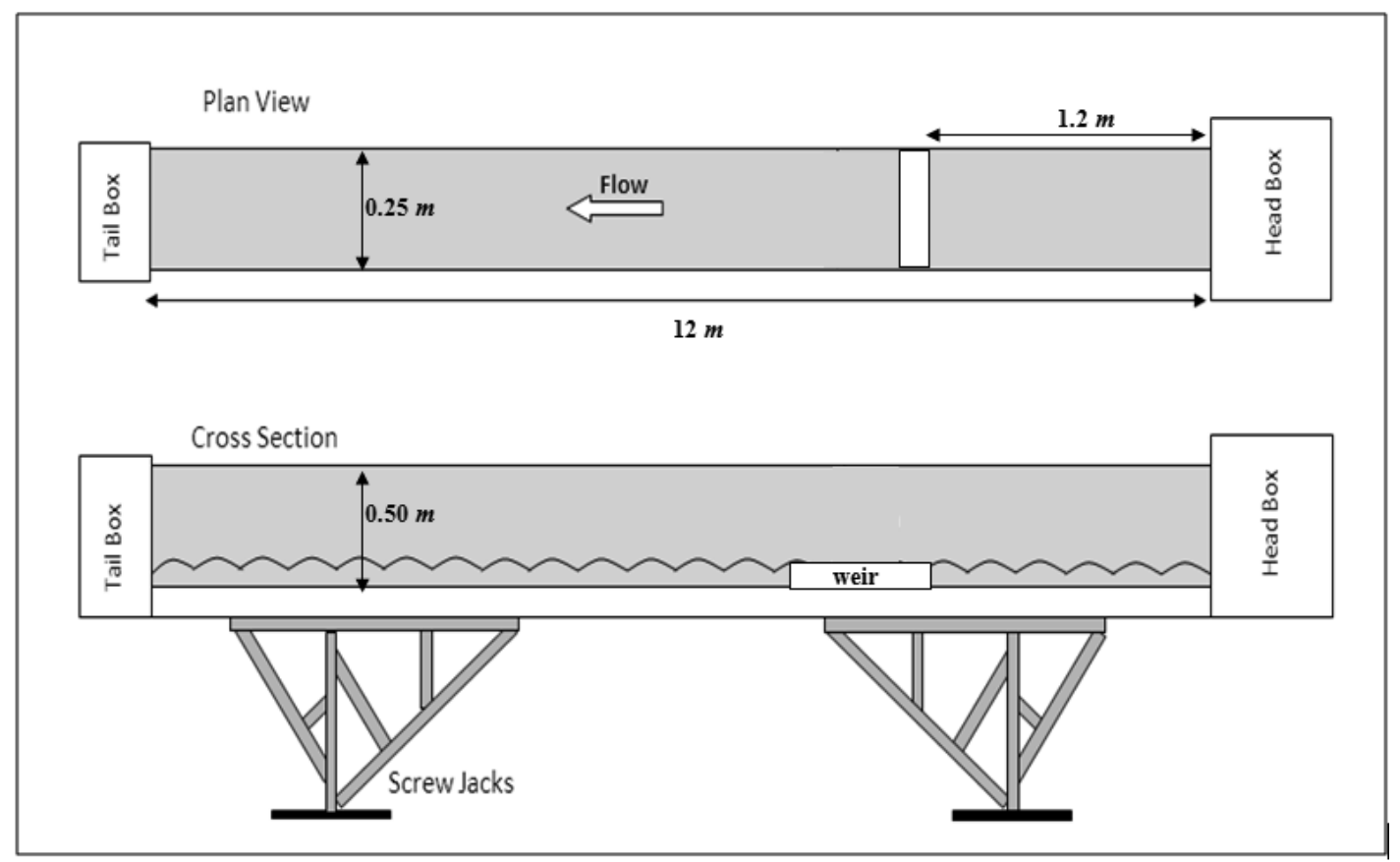

Fig. 1. Experimental channel. 


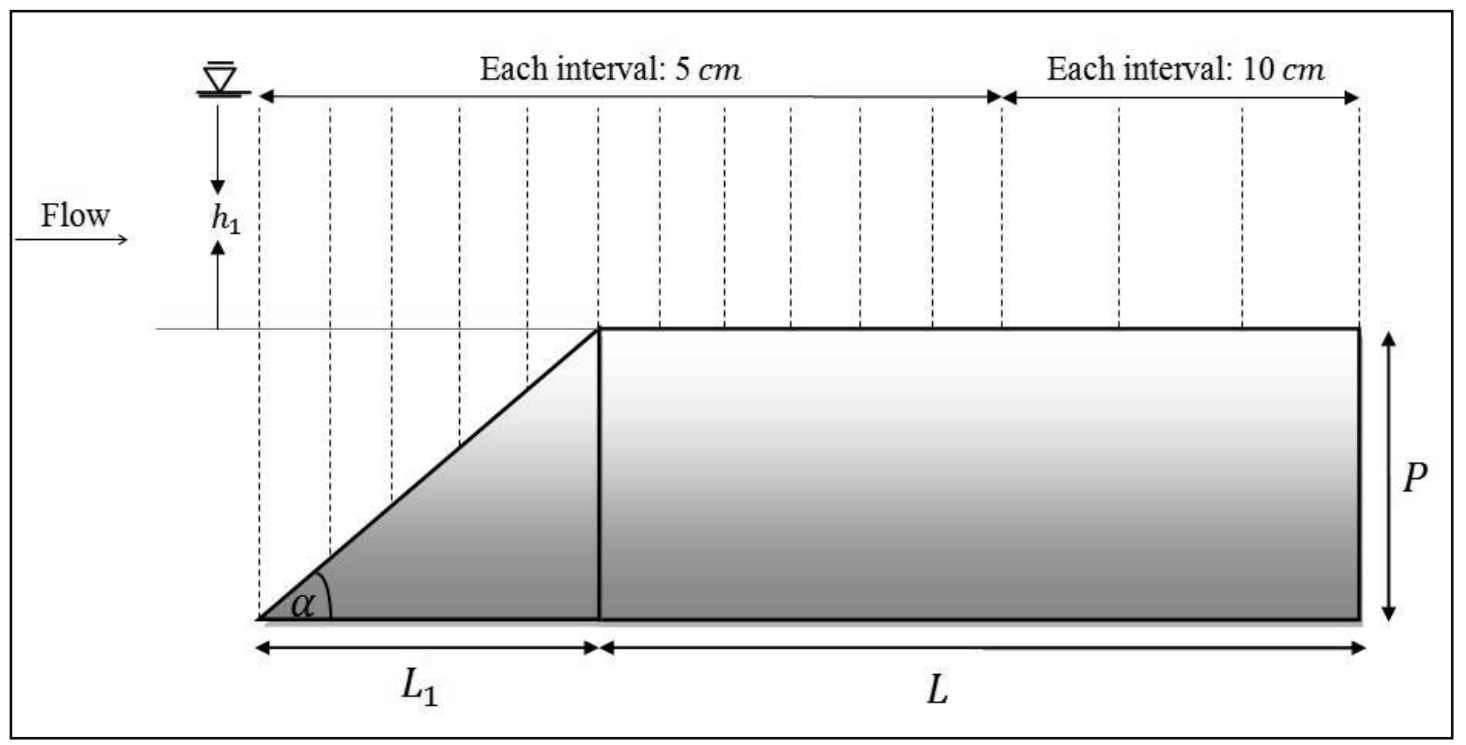

Fig. 2. Locations of measuring water surface and velocity profiles.

\section{Analysis of experimental results}

\subsection{Flow profiles}

The water surface profiles were measured for the previously described configurations and some typical water surface profiles are shown in Figs. 3, 4, and 5 for slopes of $90^{\circ}, 45^{\circ}$, and $10^{\circ}$, respectively.
Based on the presented figures, the weir with a $90^{\circ}$ upstream face slope shows a highly steep flow profile at the weir crest's entrance (Fig. 3). Evidently from Fig. 3, flow depth decreased and passed through the critical depth in the weir crest's vicinity. In addition, reduce upstream face slopes resulted in decreased approaching flow curvature and water profiles were closing to a horizontal streamline over the weir crest (Figs. 4 and 5).

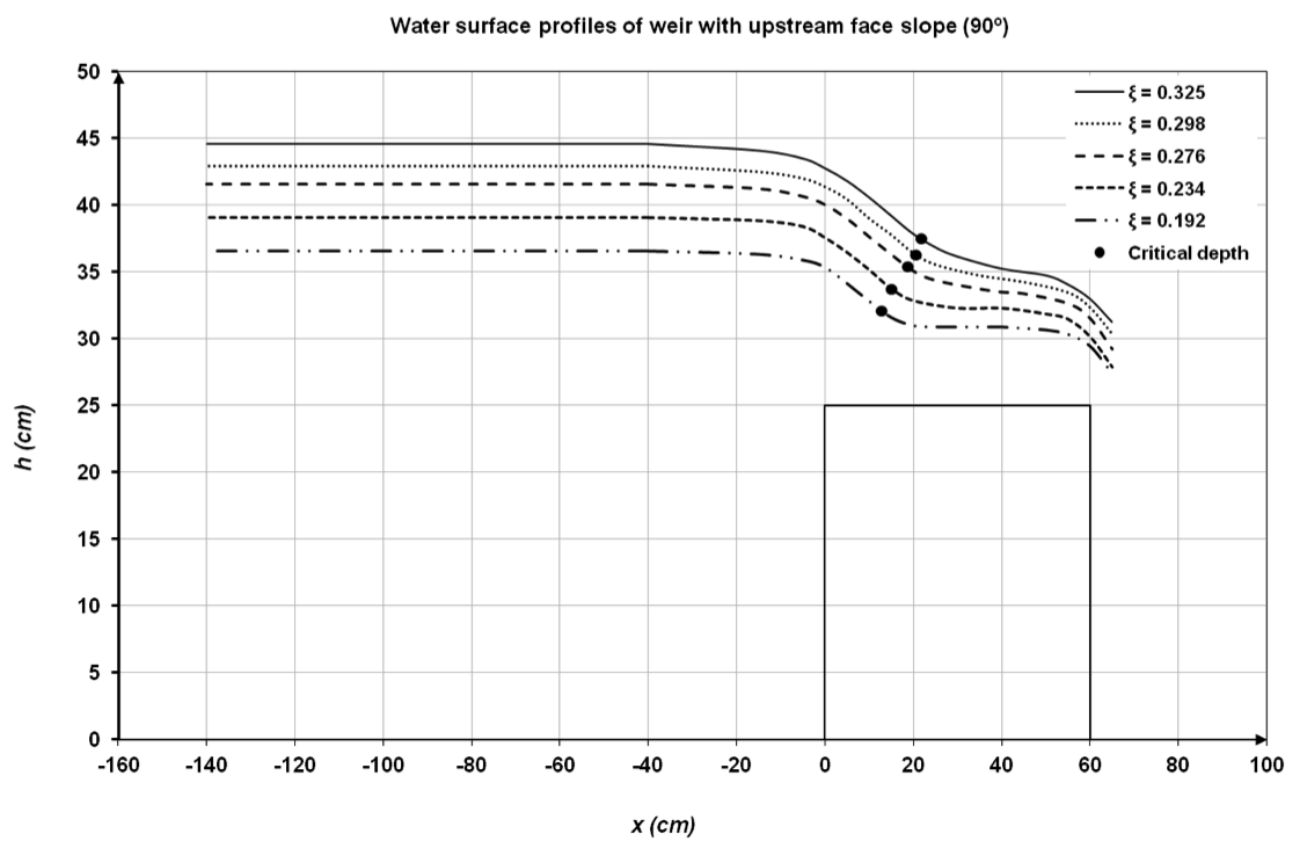

Fig. 3. Flow profiles over the standard broad crested weir $\left(90^{\circ}\right)$. 


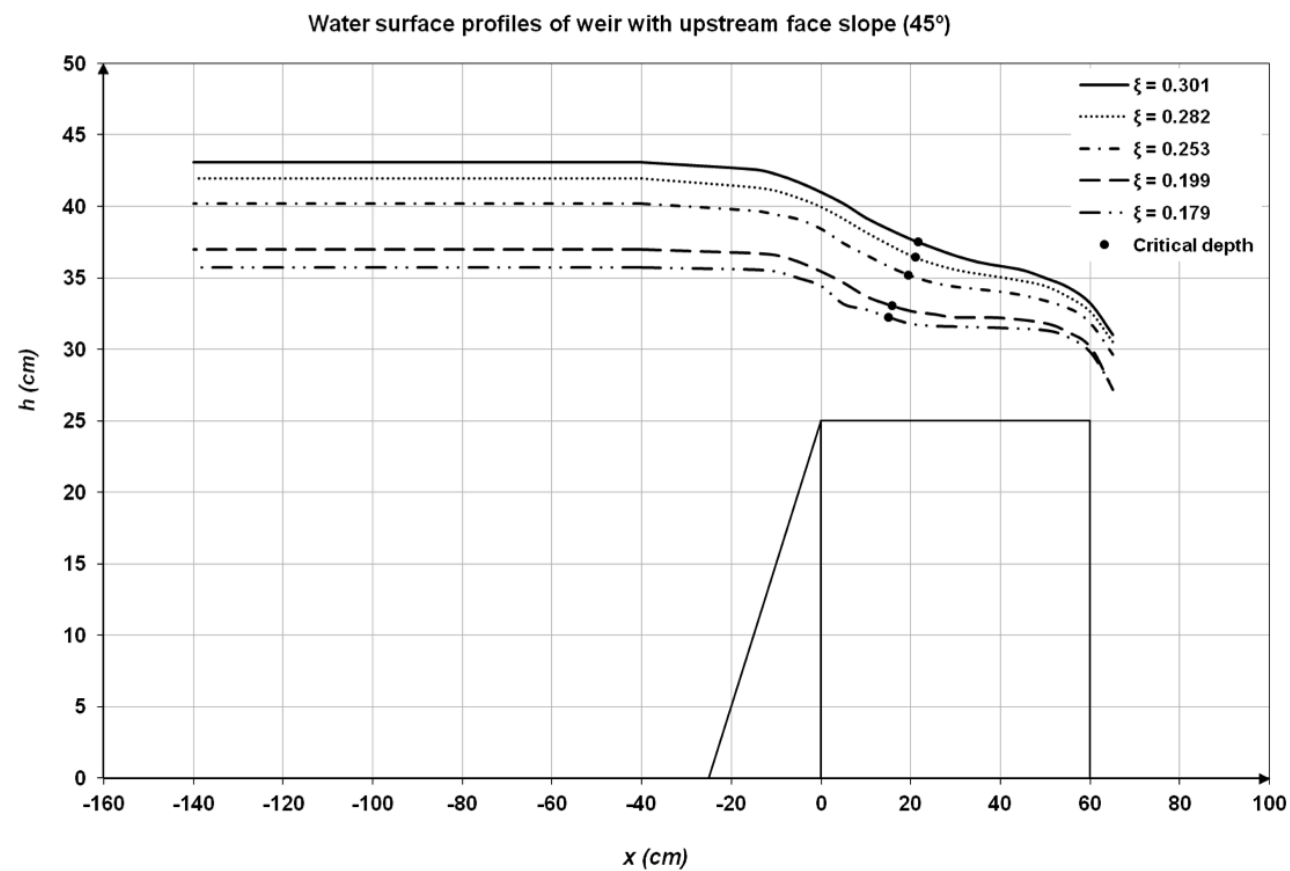

Fig. 4. Flow profiles over the weir with upstream face slope of $45^{\circ}$.

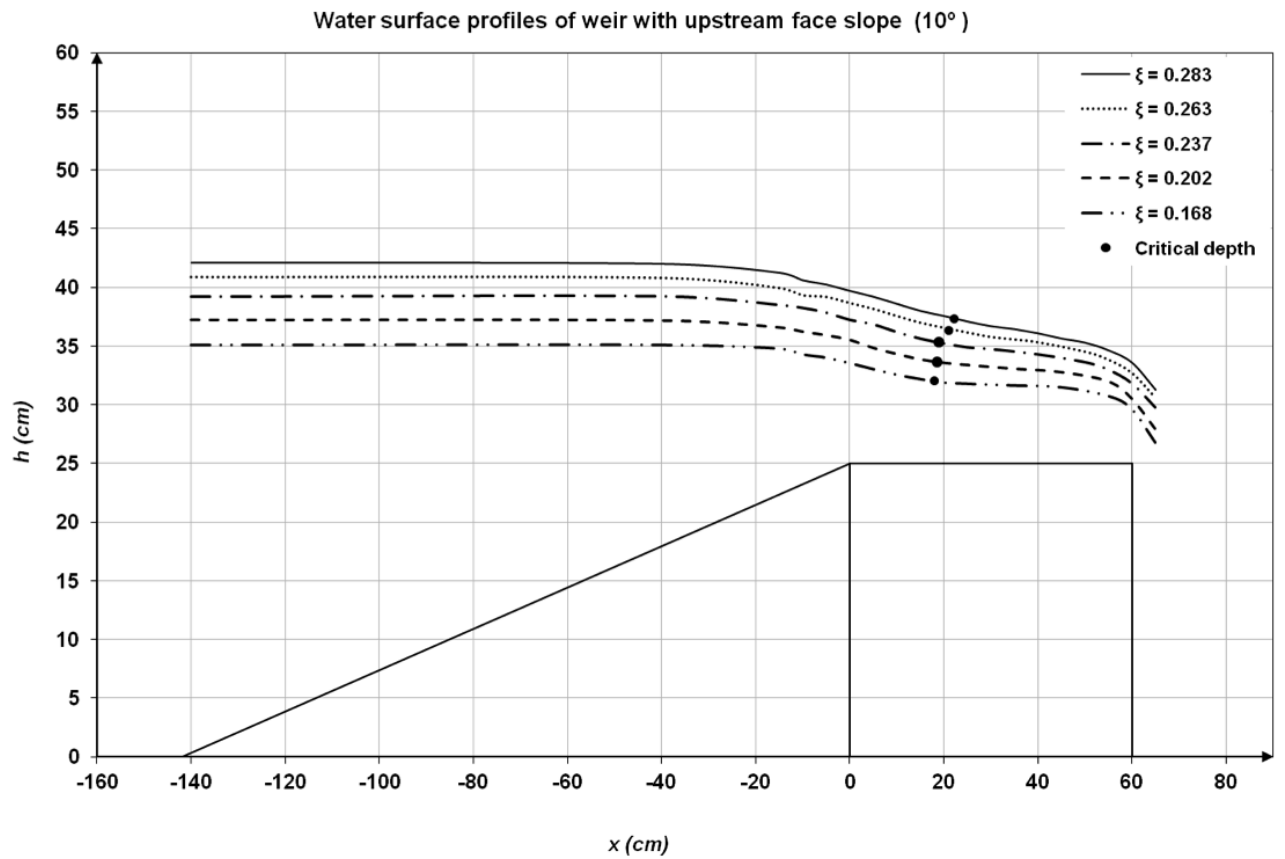

Fig. 5. Flow profiles over the weir with upstream face slope of $10^{\circ}$.

A mathematical definition was revealed for the flow profile over individual weirs as follows:

$Y=a-b\left[\tanh \left(\frac{X-c}{d}\right)\right]$, where $X=x / h_{1}, Y=h / h_{1}, x$ is the distance from the weir's entrance edge (or the edge of the weir's central part), $h$ - the overflow head, $h_{1}$ - the overflow head upstream of the weir, and $a, b, c$ and $d-$ constant coefficients for each weir, as shown in Tab. 1. 
$\mathrm{T} a \mathrm{~b} 1 \mathrm{e} 1$. The constant coefficients of governing surface profile water equation.

\begin{tabular}{cccccc}
\hline Upstream face slope & $\boldsymbol{R}^{\mathbf{2}}$ & $\boldsymbol{a}$ & $\boldsymbol{b}$ & $\boldsymbol{c}$ & $\boldsymbol{d}$ \\
\hline $90^{\circ}$ & 0.99 & 0.735 & 0.273 & 0.644 & 1.08 \\
$75^{\circ}$ & 0.99 & 0.734 & 0.273 & 0.643 & 1.08 \\
$60^{\circ}$ & 0.98 & 0.771 & 0.257 & 0.635 & 1.53 \\
$45^{\circ}$ & 0.97 & 0.772 & 0.244 & 0.635 & 1.54 \\
$30^{\circ}$ & 0.97 & 0.784 & 0.223 & 0.594 & 1.51 \\
$22.5^{\circ}$ & 0.97 & 0.784 & 0.222 & 0.595 & 1.5 \\
$15^{\circ}$ & 0.97 & 0.783 & 0.259 & 0.789 & 2.32 \\
$10^{\circ}$ & 0.97 & 0.795 & 0.229 & 0.666 & 2.11 \\
\hline
\end{tabular}

The flow profiles are sketched based on experimental results obtained from all weirs at varying flow rates, and the weir's fitted curve with an upstream face slope of $22.5^{\circ}$ is presented in Fig. 6. It should be noted that the application of Eq. (6) is limited to experimental work since it is derived from a series of laboratory experiments.

\subsection{The variation of water surface profile}

To derive the effects of changing upstream face slopes on the water surface profiles, Eq. (6) was expressed in its original parameters as:

$$
\frac{h}{h_{1}}=a-b\left[\tanh \left(\frac{\frac{x}{h_{1}}-c}{d}\right)\right]
$$

and its derivative was then computed as:

$$
\frac{d h}{d x}=\left[-\frac{b}{d}\right] \cdot\left[1-\tanh ^{2}\left(\frac{\frac{x}{h_{1}}-c}{d}\right)\right]
$$

Eq. (8) was then sketched for all weirs using all measured data and the results showed that reducing the upstream face slopes results in a declining flow profile slope accordingly (Fig. 7).

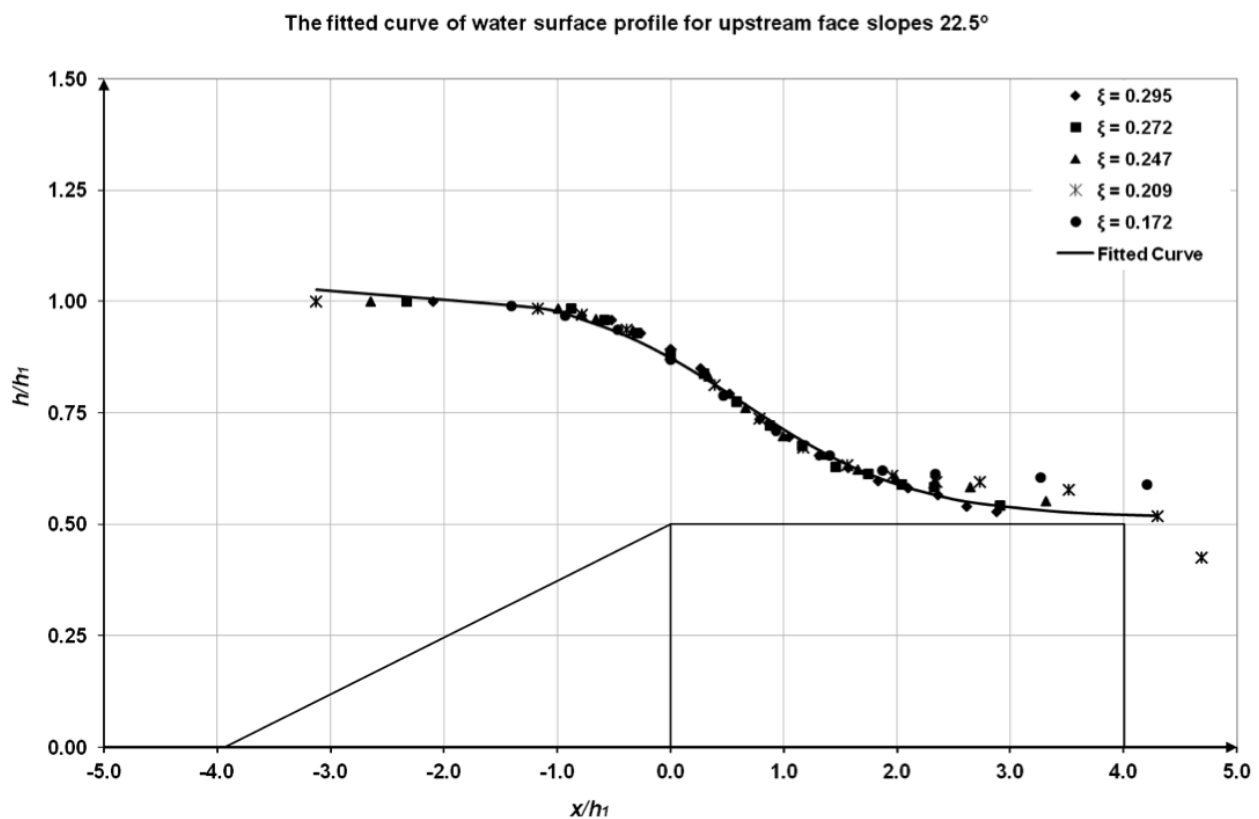

Fig. 6. Fitted flow profile over the weir with upstream face slope of $22.5^{\circ}$. 


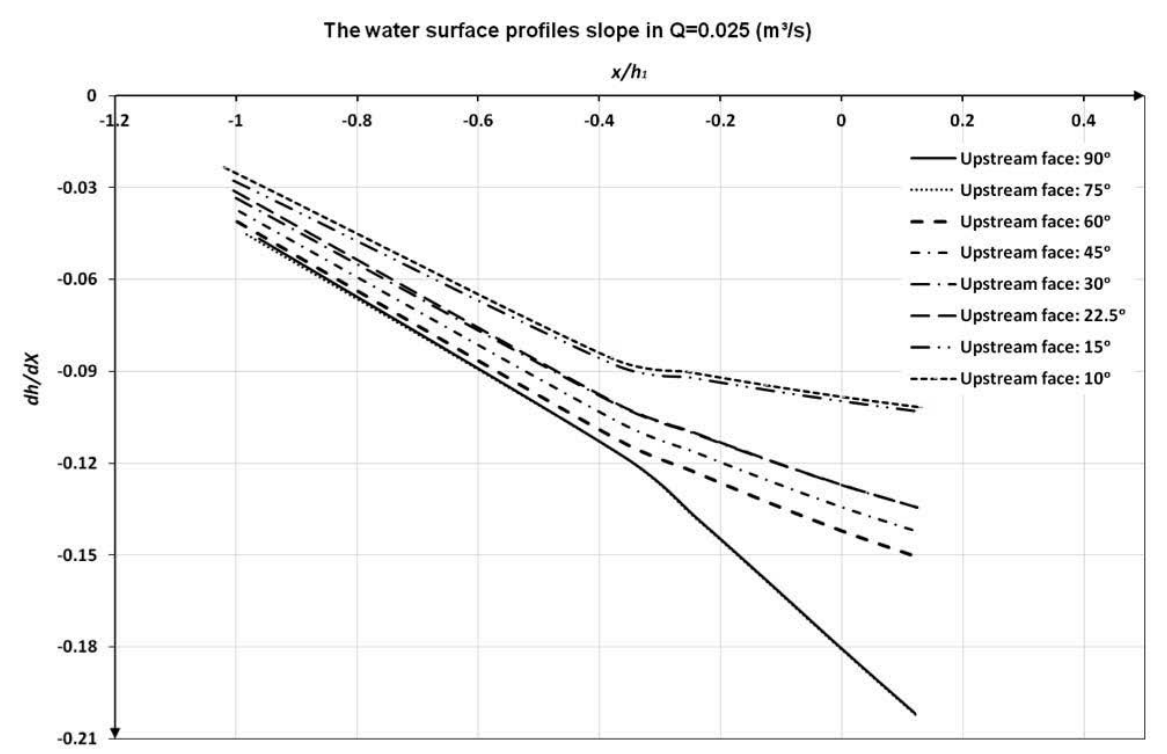

Fig. 7. Slope of water surface profiles.

\subsection{Effects of weir upstream face slope on discharge coefficient}

The free-flow discharge coefficients were computed for all weirs and results were sketched in Fig. 8 . The results revealed that the discharge coefficient increases as the upstream face slope decreases. In other words, the largest discharge coefficient occurred in the weir with upstream face slope of $10^{\circ}$ whereas in a standard broad-crested weir (upstream slope of $90^{\circ}$ ) the discharge coefficient was the smallest. The measured discharge coefficients at various flow rates are presented in Tab. 2 .

Fritz and Hager (1998) presented a correction coefficient $C_{e}$ in the formula of flow over a sharpcrested weir to obtain the flow over a broad-crested rectangular weir with a sloped upstream face as follows:

$C_{e}=1-\frac{2 \operatorname{Sin}(\alpha)}{\mathrm{g}\left(1+\zeta^{4}\right)}$

where in their study, $\xi=(h-P) / L, P$ - weir height, $L$ - crest length, $h$ - depth of flow over the crest, and $\alpha$ - the upstream face slope.

In this study, a new correction factor $C_{r}$ is presented to estimate the discharge coefficient over the rectangular broad-crested weir with different upstream face slopes by changing some parameters in Hager's equation, as follows:

$$
C_{r}=1.0+\frac{4.63 \operatorname{Cos}^{3 / 2}(\alpha)}{g\left(2.33+\xi^{4}\right)}
$$

where $P$ is weir height, $L$ - weir length, $h_{1}-$ depth upstream of the standard broad-crested weir, $\xi=h_{1} / L$, and $C_{r}$ - the ratio of weir discharge coefficient with upstream face slope $\alpha\left(C_{d_{\alpha}}\right)$ to discharge coefficient of a standard broad-crested weir $\left(C_{d_{90}}\right)$ :

$C_{r}=\frac{C_{d_{\alpha}}}{C_{d_{90}}}$.

The discharge coefficient of a rectangular broadcrested weir with an upstream face slope of $\alpha$ can be computed by calculating $C_{r}$ from Eq. (10) and applied to Eq. (11). The comparison between computed discharge coefficient based on Eqs. (10) and (11) and experimental measurements is shown in Figs. 9 and 10, respectively.

Fig. 11 shows the computed discharge coefficient in this study and other experimental data by Bazin (1896), Govinda Rao and Muralidhar (1963), Bos (1985), Hager and Schwalt (1994), ISO 3846 or British International Standard (2008), and Sargison and Percy (2009). As it can be seen in this figure, there is a good resemblance between values of discharge coefficient in this study and other experimental observations and our experimental data are in acceptable agreement with other experimental observations. 


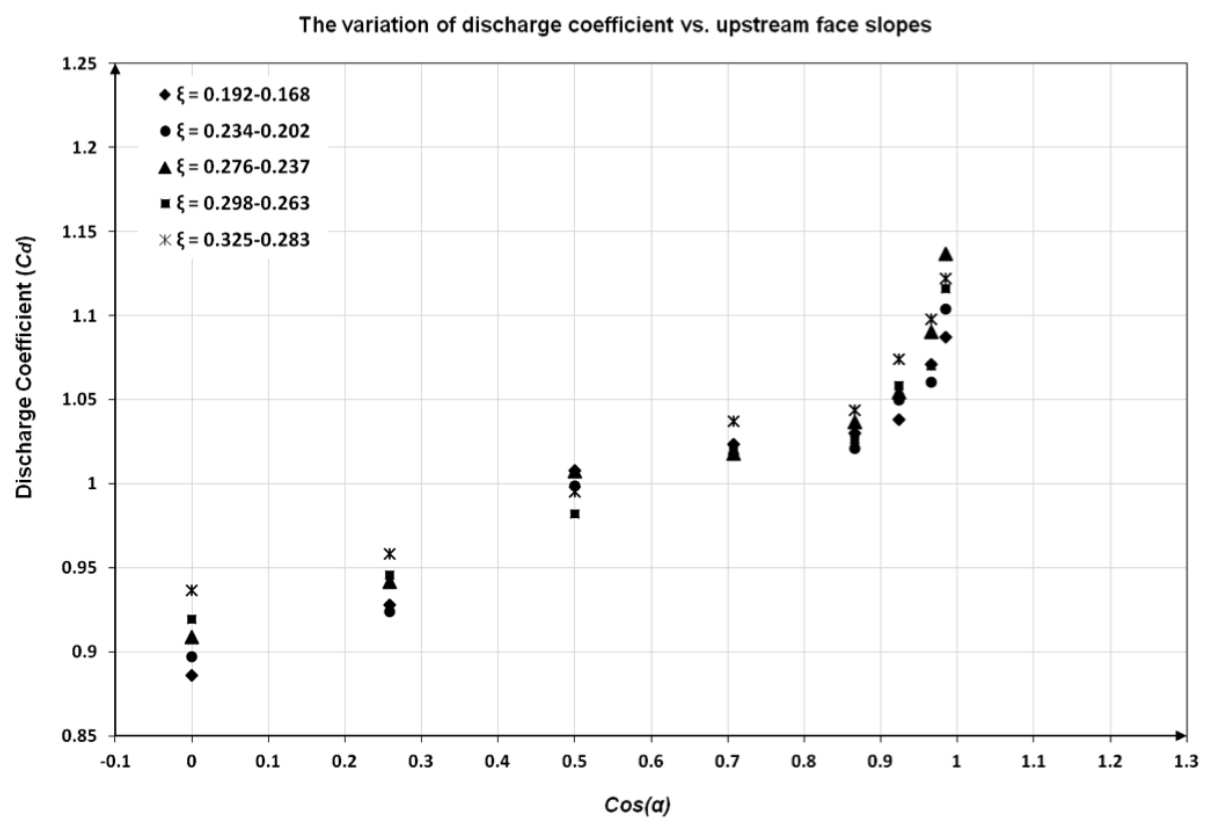

Fig. 8. Variation of discharge coefficient vs. upstream face slopes.

T a b l e 2. The measured discharge coefficients in different slopes and discharges.

\begin{tabular}{ccccccccc}
\hline \multicolumn{7}{c}{ Upstream face slopes } \\
\hline & $90^{\circ}$ & $75^{\circ}$ & $60^{\circ}$ & $45^{\circ}$ & $30^{\circ}$ & $22.5^{\circ}$ & $15^{\circ}$ & $10^{\circ}$ \\
\hline$Q\left[\mathrm{~m}^{3} \mathrm{~s}^{-1}\right]$ & & & \multicolumn{7}{c}{ Discharge coefficient $\left(C_{d}\right)$} \\
\hline 0.015 & 0.8859 & 0.9283 & 1.0078 & 1.0235 & 1.0300 & 1.0380 & 1.0711 & 1.0872 \\
0.020 & 0.8971 & 0.9241 & 0.9989 & 1.0172 & 1.0212 & 1.0498 & 1.0605 & 1.1037 \\
0.025 & 0.9089 & 0.9414 & 1.0073 & 1.0180 & 1.0368 & 1.0542 & 1.0900 & 1.1365 \\
0.030 & 0.9195 & 0.9456 & 0.9821 & 1.0212 & 1.0259 & 1.0583 & 1.0708 & 1.1160 \\
0.035 & 0.9364 & 0.9582 & 0.9951 & 1.0370 & 1.0436 & 1.0743 & 1.0976 & 1.1220 \\
\hline
\end{tabular}

\subsection{Separation zone}

When flow reaches to a rectangular weir with square upstream edge, the flow separates from the upstream edge and does not reattach to the weir before the flow leaves the weir (Azimi and Rajaratnam, 2009). Experimental observations showed that upstream corner rounding and varying upstream slope change the weir inflow geometry and had a major impact on the flow pattern and separation zone over the crest (Bazin,1896; Sargison and Percy, 2009). The separation zones and eddies tend to complicate the flow pattern over the weir and alter the velocity distribution in the stream (Chow, 1959). The results of this study revealed that varying upstream face slope of rectangular broadcrested weir has major influence on the flow sepa- ration from the upstream crest and flow over a separated crest zone.

Based on the results, weirs with a $90^{\circ}$ upstream face slope experienced flow separation at the upstream edge, and developing separation zone affected the velocity profile and pressure distribution over the crest. According to the literature, there is an inverse relationship between discharge coefficient $\left(C_{d}\right)$ and the overflow head upstream of the weir $\left(h_{1}\right)$ along the flow direction (Eq. (2)). So, developing the separation zone by increasing flow head would impose a negative effect on the weir's discharge coefficient and it would inversely influence $C_{d}$. It was observed that as the upstream face slope decreased, the effect of weir entrance edge on flow separation was diminished and resulted in gradual dissipation of the separation zone. 


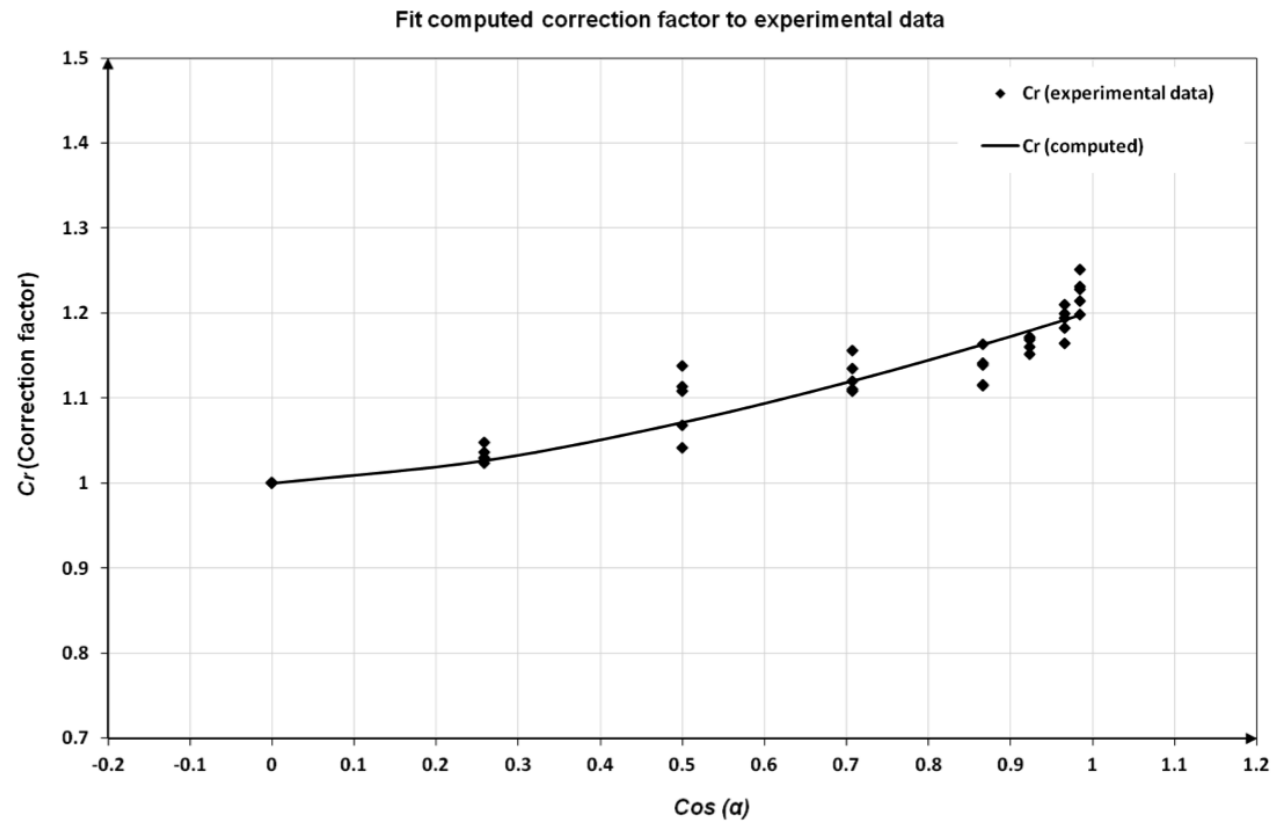

Fig. 9. Fit computed correction factor to experimental data.

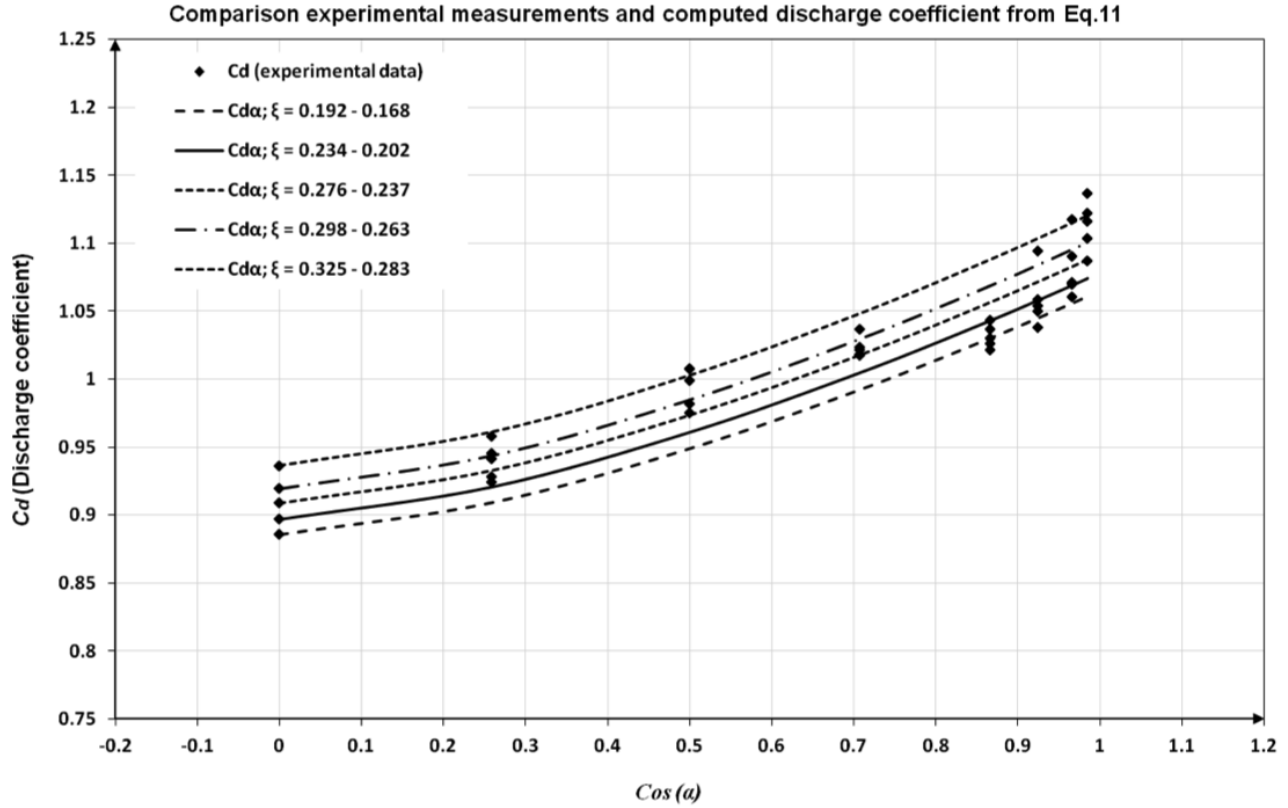

Fig. 10. Comparison experimental and computed discharge coefficient from Eq. (11). 


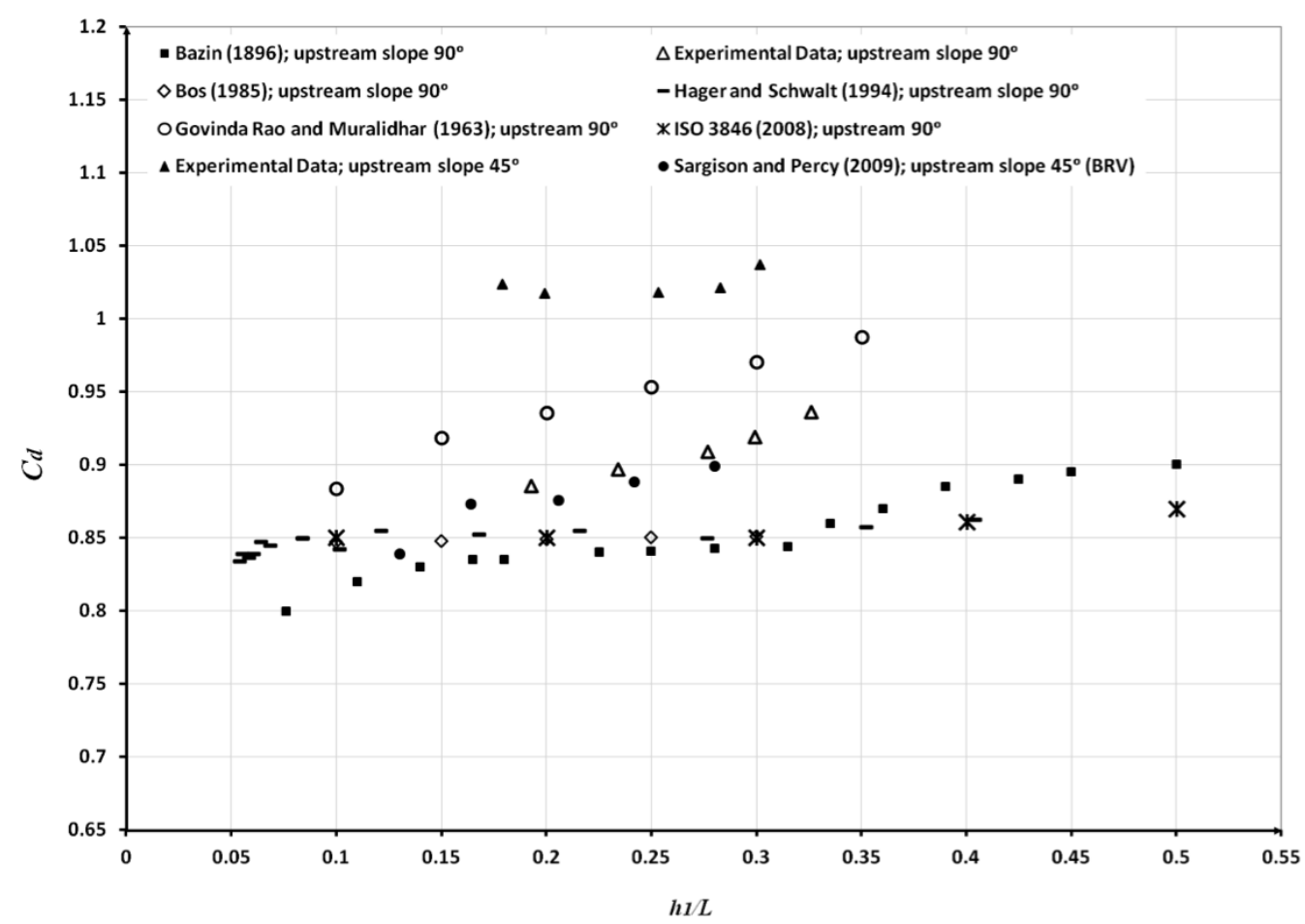

Fig. 11. Comparison the computed discharge coefficient in this study and other experimental data.

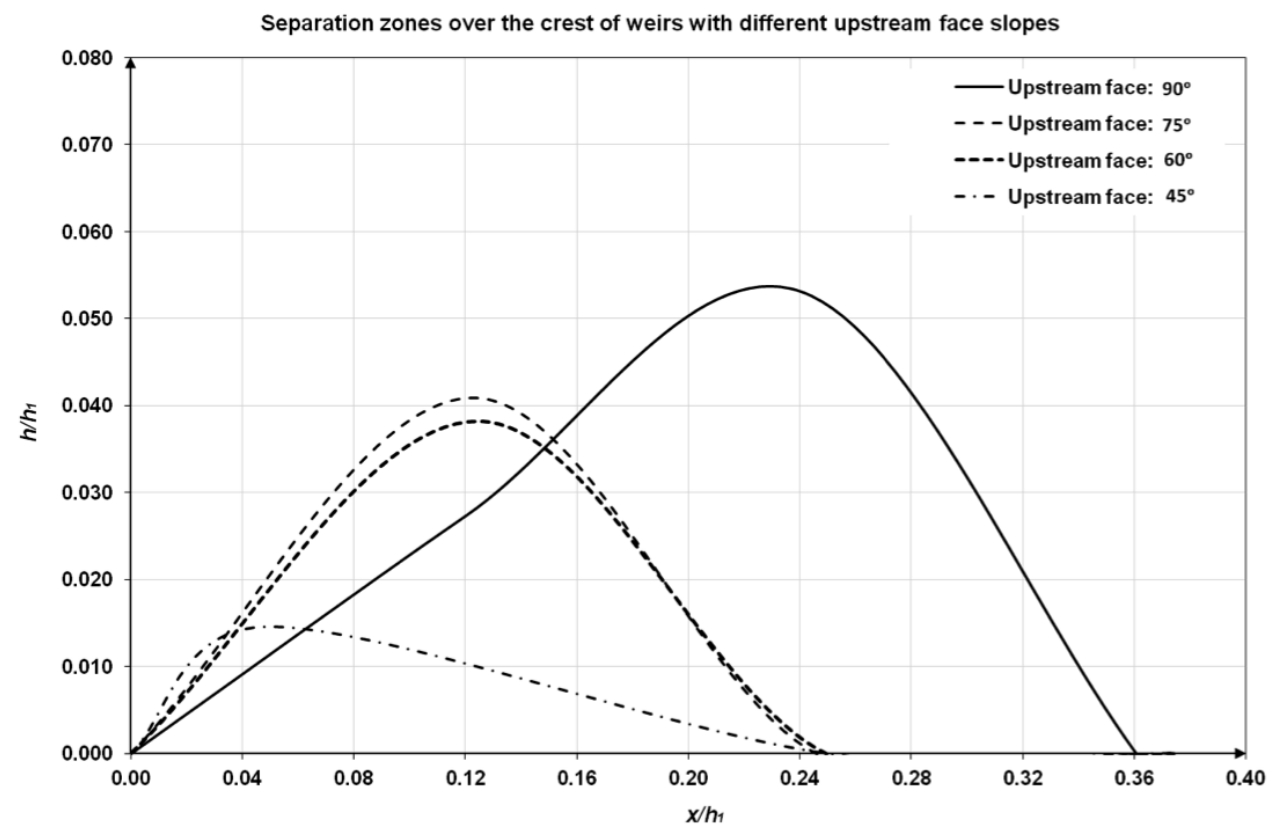

Fig. 12. Separation zone over the crest of upstream sloped weirs.

To demonstrate the effect of upstream face slope on flow separation characteristics, the flow separation length was plotted against flow depth and is shown in Fig. 12. In this figure, the largest separation length occurred in the weir with a $90^{\circ}$ upstream face slope and it gradually reduced with decreasing upstream face slope. The results demonstrate that the maximum coordinates of flow separation zone fell at $x / h_{1}=0.240$ and $h / h_{1}=0.053$. 


\subsection{Velocity profiles}

Flow velocity profiles were measured over the crest using a pitot tube on a traverse apparatus at different static points spaced between 0.05 and 0.10 $\mathrm{m}$ apart (Fig. 2). Various dimensionless velocity profiles were plotted and the results are presented in Figs. 13 to 15. Based on Fig. 13, the velocity values along the flow direction increase and flow passes form sub-critical to the super-critical condition. In addition, flow velocity tends to be zero at the standard weir's entrance edge and higher than zero at the entrance edge of weirs with upstreamsloped faces, reflecting an easy flow pass through the weir crest. Furthermore, the separation zone which occurred at the weir's edge and with flow velocity becoming negative was diminishing by reduced upstream face slopes. No negative velocity was observed for weirs with upstream face slopes less than $45^{\circ}$ (Figs. 14 and 15).

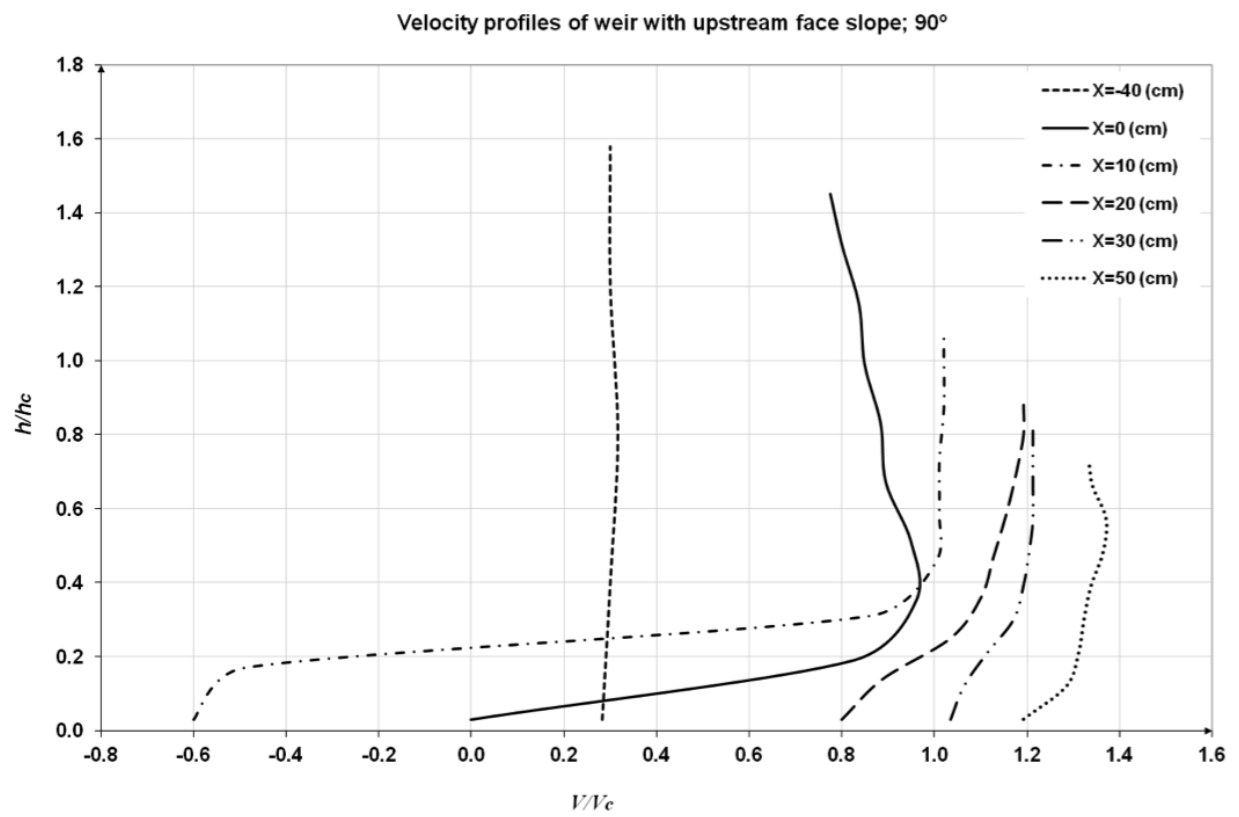

Fig. 13. Velocity profiles of weir with upstream face slope of $90^{\circ}$.

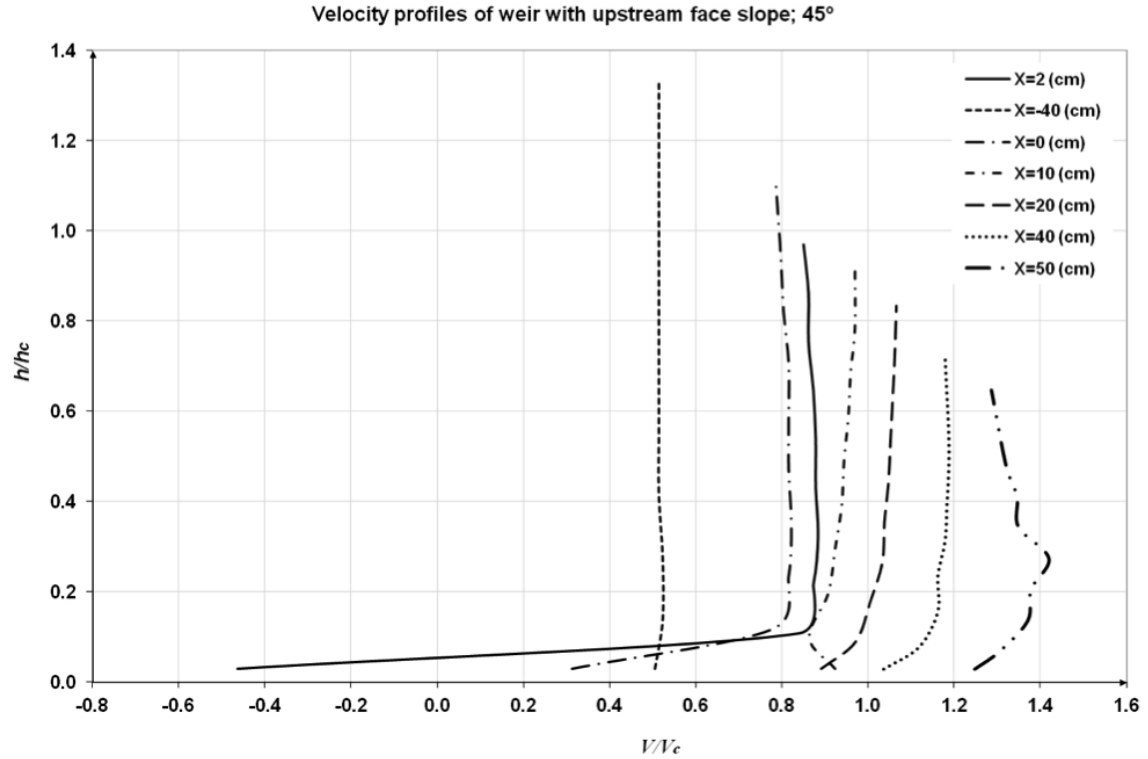

Fig. 14. Velocity profiles of weir with upstream face slope of $45^{\circ}$. 


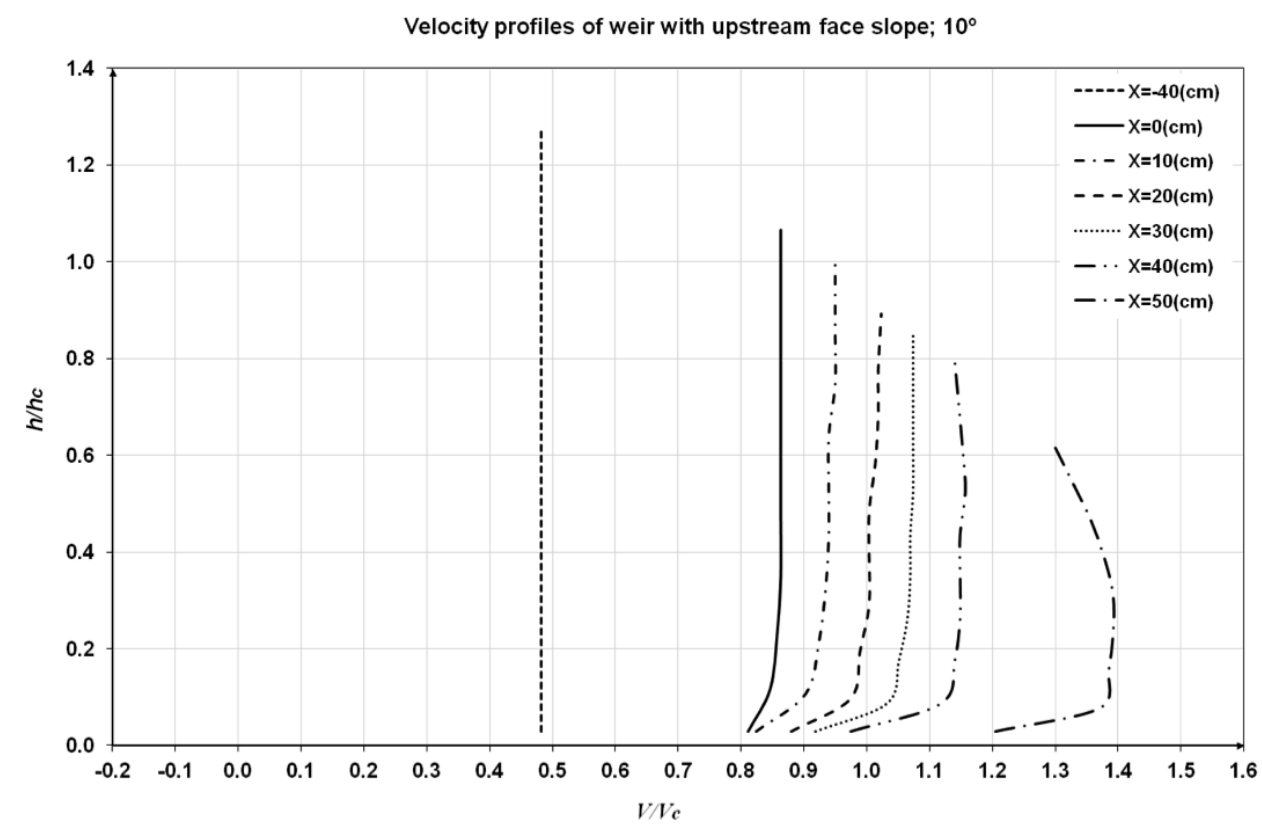

Fig. 15. Velocity profiles of weir with upstream face slope of $10^{\circ}$.

\section{Sources of errors}

The most significant errors occurring in indirect discharge measurements using different hydraulic structures such as broad-crested weirs can be written as follows:

1. The way in which the head $h_{1}$ is measured and the method of registering of both water level and crest level,

2. Errors in calibration affecting the reliability of the characteristic discharge coefficient $C_{d}$,

3. The weakness of the pitot tube in measuring static head in curvilinear flow,

4. Errors in structure dimensions, and

5. As the used laboratory flume was a narrow channel (the ratio of width to depth is less than 5), the side walls can produce anisotropic turbulence that creates secondary currents in the crosssection and effect on the maximum velocity and velocity profile (Nezu and Nakagawa, 1993).

\section{Conclusions}

In this study, a series of laboratory experiments were conducted to investigate the effect of changing upstream slope of rectangular broad-crested weirs on discharge coefficient, velocity profile, and the flow separation zone. By analyzing experimental results, the following conclusions can be drawn:
1. The discharge coefficient related to overflow energy heads varies with the relative upstream slope. Decreasing upstream face slope makes the water surface profile fall into smooth curvature and become flatter. Also, the discharge coefficient tends to increase with decreasing upstream weir slope. Thus, weirs with upstream face slopes of $90^{\circ}$ and $10^{\circ}$ have the smallest and largest discharge coefficient, respectively. The weir discharge coefficient value at a $10^{\circ}$ slope is about $22 \%$ higher than for a weir with a $90^{\circ}$ upstream face slope. In addition, a new correction factor $C_{r}$ was presented to estimate the discharge coefficient of rectangular broad-crested weirs with different upstream face slopes.

2. The flow profiles of individual weirs falling in a hyperbolic equation with different coefficients and constant values for each weir as well as the appropriate mathematical definitions were presented.

3. Flow separation occurs at the edge of rectangular broad-crested weirs and extends to a certain point over the crest. Regarding the separation, flow velocity becomes negative through this zone. Decreasing upstream face slope reduces the separation zone and so the negative velocity would not occur at the weir entrance. Hence, there was no negative velocity in weirs with upstream slopes of less than $45^{\circ}$. 
Based on the results, we can conclude that the upstream weir design has a considerable effect on the flow pattern and discharge coefficient of rectangular broad-crested weir, and the performance of this structure is optimized by varying the upstream slopes.

Acknowledgments. I would like to acknowledge deeply from Eng. Mina Ziaei, and Eng. Majid Mirzaei who contributed during the research.

\section{List of symbols}

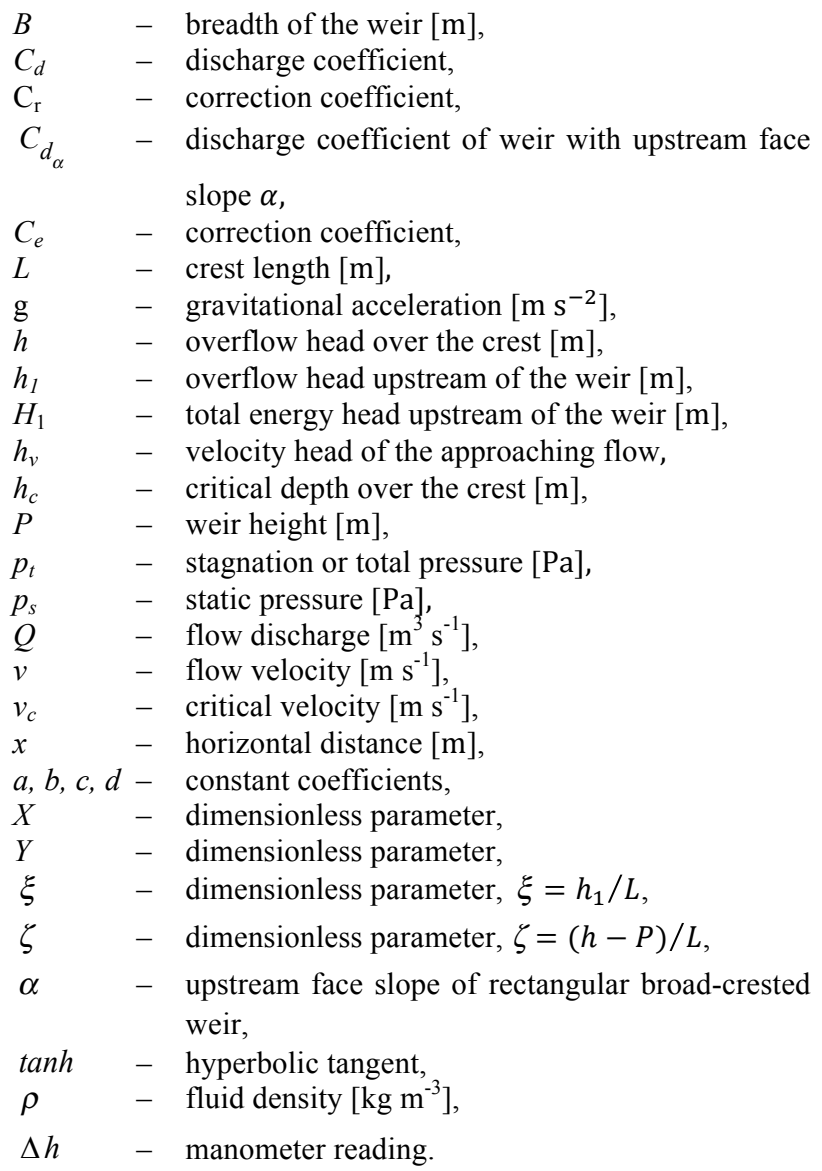

\section{REFERENCES}

AZIMI A. H., RAJARATNAM N., 2009: Discharge Characteristics of Weirs of Finite Crest Length. J. Hydraul. Engng., Vol. 135, 12, 1081-1085.

BAYLAR A., EMIROGLU E. M., 2002: The effect of sharpcrested weir shape on air entrainment. Canad. J. Civ. Engng., 29, 3, 375-383.

BAZIN H., 1896: Expériences Nouvelles sur 1'Ecoulement par Déversoir. Recent experiments on the flow of water over weirs. (In French.) Mémoires et Documents, Annales des Ponts et Chaussées, Séries 7, 12, 2, 645-731.

BETTEZ J., TOWNSEND R. D., COMEAU A., 2001: Scale model testing and calibration of City Ottawa sewer weirs. Can. J. Civ. Eng., 28, 627-639.
BHASKAR R., NIGAM A., 1990: Qualitative physics using dimensional analysis. Artificial Intelligence, 45, 73-111.

BOITEN W., 1993: Flow-measuring structures. Delf Hydraulics, Wageningen Agricultural University, Nieuwe Kanaal, Wageningen, The Netherlands.

BORGHEI S., KABIRI-SAMANI A.R., NEKOEE N., 2006: Oblique weir equation using incomplete self-similarity. Canad. J. Civ. Engng., 33, 10, 1241-1250.

BOS M. G., 1985: Broad-crested weirs and long-throated flume., Martinus Nijhoff, Dordrecht, The Netherlands.

BRITISH INTERNATIONAL STANDARD, ISO 3846, 2008: Hydrometry Open channel flow measurement using rectangular broad-crested weirs.

CHOW V. T., 1959: Open Channel Hydraulics. McGraw-Hill, Inc.

FARHOUDI J., SHAHALAMI H., 2005: Slope effect on discharge efficiency in rectangular broad crested weir with sloped upstream face. Int. J. Civ. Engng.,V 3, N1.

FARHOUDI J., SHOKRI N., 2007: Flow from broad crested rectangular weirs with sloped downstream face. 32nd IAHR Congress, Venice, Italy.

FRITZ H. M., HAGER H. W., 1998: Hydraulics of Embankment Weirs. J. Hydraul. Engng., ASCE., 124, 9, 963-971.

GHODSIAN M., 2003: Supercritical flow over a rectangular side weir. Canad. J. Civ. Engng., 30, 3, 596-600.

GOVINDA RAO. N. S., MURALIDHAR D., 1963: Discharge characteristics of weirs of finite-crest width. La Houille Blanche, 5, 537-545.

HALL G. W., 1962: Analytical determination of discharge characteristics of broad-crested weirs using boundary layer theory. Proc.-Inst. Civ. Eng., 22, 172-190.

HAGER, H. W., and SCHWALT, M., 1994: Broad-crested weir. J. Irrig. and Drainage Engng., 120, 1.

HARRISON A. J. M., 1967: The streamlined broad-crested weir. Proc.-Inst. Civ. Eng., 38, 657-678.

HAUN S., OLSEN N.R.B., FEURICH R., 2011: Numerical modeling of flow over trapezoidal broad-crested weir. Engineering Application of Computational Fluid Mechanics, Vol. 5, No. 3, pp. 397-405.

NEZU I., and NAKAGAWA H., 1993: Turbulence in open channel flow. IAHR-Monograph. Rotterdam: A. A. Balkema Publishers.

RAMAMURTHY A. S., UDOYARA S. T., RAO M. V. J., 1988: Characteristic of square-edged and round-nosed broad-crested weirs. J. Irrig. Drain. Eng., 114-1, 61-73.

RAMAMURTHY J., TADAYON A. S. R., CHEN Z., 2009: Numerical simulation of sharp-crested weir flows. Canadian J. of Civil Engng., 36, 9, 1530-1534.

RAO S. S., SHUKLA, M. K., 1971: Characteristics of flow over weirs of finite crest width. J. Hydraul. Div., Am. Soc. Civ. Eng., 97-11, 1807-1816.

SARGISON J. E., AND PERCY A., 2009: Hydraulics of Broad-Crested Weirs with Varying Side Slopes. J. of Irrigation and Drainage Engng., ASCE. Vol. 135, No. 1, 115-118 .

SINGER J., 1964: Square-edged broad-crested weir as a flow measurement device. Water and Water Engng., 28, 820, 229-235.

WOODBURN J. G., 1932: Tests on the Broad-crested weirs. Trans. ASCE, 1797, 96, 387-408.

Received 24 May 2011 Accepted 13 March 2012 